This is the peer reviewed version of the following article: $R S C A d v$., 2015, 5, 87352-87363, which has been published in final form http://pubs.rsc.org/en/content/articlelanding/2015/ra/c5ra10027e\#! divAbstract

\title{
Clickable Complexing Agents: Functional Crown Ethers for Immobilisation Onto Polymers and Magnetic Nanoparticles
}

\author{
Carolina Mendoza, ${ }^{a}$ Susanna Jansat, ${ }^{a}{\text { Ramón } \text { Vilar }^{b} \text { and Miquel A. Pericàs }}^{* a, c}$ \\ Crown ethers and monoazacrown ethers supported onto well defined cobalt and $\mathrm{Fe}_{3} \mathrm{O}_{4}$ magnetic \\ nanoparticles have been prepared and used as magnetically recoverable extracting materials for $\mathrm{Pb}^{2+}$ from \\ aqueous and organic solutions. The assembly of the functional nanoparticles involves the integration of \\ 10 the complexing units by means of a copper-catalysed alkyne-azide cycloaddition reaction leading to a \\ 1,2,3-triazole linker. The same binding motifs have been also used to functionalise polystyrene (PS) and \\ polystyrene-polyethyleneglycol (PS-PEG) resins, and the resulting materials were also employed in the \\ removal of $\mathrm{Pb}^{2+}$ from solutions. The relative merits of these two approaches are compared.
}

\section{Introduction}

${ }_{15}$ Crown ethers, for their extraordinary ability to bind cations, have revolutionised the field of coordination chemistry since its introduction in the late 60 's of the last century. ${ }^{1}$ The removal of metal ions from aqueous and organic solutions is a subject of great interest due to the high environmental impact associated 20 with the presence of toxic heavy metal (e.g. $\mathrm{As}^{\mathrm{III}}, \mathrm{As}^{\mathrm{V}}, \mathrm{Cd}^{2+}, \mathrm{Hg}^{2+}$ and $\left.\mathrm{Pb}^{2+}\right)$ in clean and waste waters, ${ }^{2}$ the recovery of highly valuable metals used in industry and jewellery (e.g. Pt, Pd or $\mathrm{Au})^{3}$ and even the removal of metals from the body after exposure and contamination. $^{4}$

25 A potentially important, yet underdeveloped approach for the removal of metal cations from solutions is represented by the use of complexing agents that could be readily separated from the solution once loaded with the target contaminants. Metal oxides, for instance, have the ability to bind metal ions in solution, by 30 adsorption and ion exchange mechanisms. ${ }^{5}$ Therefore, a number of remediation techniques make use of the sorptive and extracting properties of metal and metal oxide nanomaterials to remove or stabilise inorganic, organic and radioactive contaminants. ${ }^{6}$

Functional magnetic nanoparticles (MNPs) ${ }^{7}$ stabilized with 35 ligands that have the ability to coordinate metal cations could be applied in metal recovery and in decontamination processes. In this approach, the ligands decorating the nanoparticle's surface would bind the cations, and the nanoparticles could then be removed from the solution by the application of an external 40 magnetic field. Recently, some examples of this approach have appeared in the literature. ${ }^{8}$ MNPs encapsulated by a thiol containing polymer have been used as adsorbent for $\mathrm{Pb}^{2+}, \mathrm{Ag}^{+}$ and $\mathrm{Hg}^{2+}$. Also, thiol functionalised superparamagnetic iron oxide $\left(\mathrm{Fe}_{3} \mathrm{O}_{4}\right)$ nanoparticles $(5.8 \mathrm{~nm})$ have been reported for the 45 removal of heavy metal ions from aqueous solutions, ${ }^{10}$ and a fluorescent receptor for $\mathrm{Pb}^{2+}$ has been reported using a diaza-sindacene ligand bound to magnetic nickel nanoparticles (30-40 $\mathrm{nm}) .{ }^{11}$ In a recent report, an ethylenediamine tetraacetic acid-like ligand has been placed onto the surface of carbon coated 50 nanomagnets and used in the removal of cadmium, lead and copper from contaminated water. ${ }^{12}$

Polymeric materials can also be used for the separation of metal ions from solutions. Setting apart the classical ion exchange resins, a more specific interaction with the metal ion can be 55 achieved through the functionalisation of polymers with ligands containing donor atoms with affinity for the target metal. For example aminobenzo-18-crown-6 and aminomethyl-18-crown-6 ethers bonded to Merrifield resin have been used for the separation of alkaline and alkaline-earth isotopes $\left(\mathrm{Li}^{+}, \mathrm{Mg}^{2+}\right)^{13}$ 60 and aza-crown ethers immobilised onto a copolymer of ethylene glycol methacrylate and glycidyl methacrylate were used in the extraction of metal ions $\left(\mathrm{Ag}^{+}, \mathrm{Pb}^{2+}, \mathrm{Cd}^{2+}\right)$ from aqueous solutions. ${ }^{14}$

We reasoned that, for future applications, it would be ${ }_{65}$ interesting to develop immobilisation strategies suitable for the incorporation of the same complexing agents onto different platforms. In this way, libraries combining sets of receptors with sets of suitably functionalized supports (organic polymers and magnetic nanoparticles) could be easily constructed and this 70 could allow the ready optimization of the resulting modular detoxification agents for specific situations.

Probably the most general synthetic strategy available today for the predictable and fully reliable combination of molecular fragments is the copper-catalyzed alkyne-azide cycloaddition 75 (CuAAC) reaction, ${ }^{15}$ the archetypal example of click chemistry. ${ }^{16}$ Over the last years, we and other groups ${ }^{17,18}$ have demonstrated the validity of this strategy for the immobilization of catalytic species without negative effects on either catalytic activity or stereoselectivity, and we considered that it would be particularly ${ }_{80}$ suitable for the purpose of this research. ${ }^{19,20}$

As part of the ongoing work in our group on the preparation of functional $\varepsilon$-cobalt ${ }^{21}$ and $\mathrm{Fe}_{3} \mathrm{O}_{4}{ }^{22}$ magnetic nanoparticles (MNPs) as easily recoverable and reusable catalysts, ${ }^{23}$ we decided to use these nanomaterials, functionalized in their surfaces with azido 85 groups, as platforms for the grafting of cation receptors. In the same manner, azido-functionalised polystyrene (PS, Merrifield type) and polystyrene-polyethyleneglycol (PS-PEG) resins would also be used as immobilization platforms. This set of materials could provide different alternatives with respect to the nature of 90 the solution to be detoxified (aqueous or organic) and with respect to the separation technique to be used (simple filtration or magnetic decantation). 


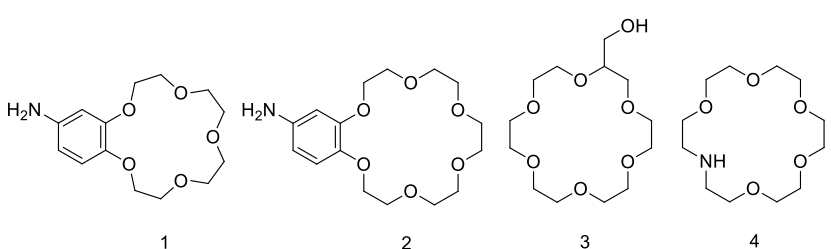

Figure 1 Crown ethers and azacrown ethers suitable for the preparation of metal extracting composites.

Crown ethers and aza-crown ethers 1-4 (Figure 1) are suitable 5 binding motifs for their ready availability and for the high selectivity depicted in front of various types of metal ions and for their adaptability to the strategy envisaged for anchoring them to the different platforms. Thus, all of them can be easily functionalized by alkylation to species containing terminal alkyne 10 moieties. These structures are well known for their ability to act as ligands for a wide range of metal ions and cationic organic species $^{24}$ for different purposes but, to our knowledge, MNPs functionalised with crown ether have not yet been used for the removal of cations from solutions. ${ }^{25}$

15 We report in the present paper the preparation of a family of immobilised functional crown ethers prepared according to the principles outlined above. Units 3 and 4, involving binding through different atoms and positions (exo- and endocyclic) were selected for this study. As a model system to test their ${ }_{20}$ performance we have selected the extraction of $\mathrm{Pb}^{2+}$ from aqueous and organic solutions. The 18-crown-6 and 1-aza-crown6 units have been shown to bind this metal cation with a significant association constant. According to literature data, association constants for the binding of the unsubstituted 1825 crown- 6 with $\mathrm{Pb}^{2+}$ are in the range of $\log K=3.58-4.27$ in water, ${ }^{26,27} \log K=6.99$ in methanol, ${ }^{27}$ and $\log K=6.5$ in a $70: 30$ $\mathrm{v} / \mathrm{v}$ methano:water mixture, ${ }^{28}$ while the 1 -aza-18-crown-6 (4), binds to $\mathrm{Pb}^{2+}$ with an even larger association constant, $\log K=8.4$ in a methanol/water $(95: 5 \mathrm{v} / \mathrm{v})$ mixture, at $25^{\circ} \mathrm{C}^{29}$

\section{Results and discussion}

\section{Synthesis of functionalised cobalt nanoparticles}

Monodisperse cobalt nanoparticles can be synthesised through 35 the thermal decomposition of organometallic compounds in highboiling organic solvents containing stabilizing surfactants. ${ }^{30}$ Puntes et al. reported the use of cobalt octacarbonyl $\left[\mathrm{Co}_{2}(\mathrm{CO})_{8}\right]$ in the presence of a mixture of surfactants as a way to obtain $\varepsilon$ phase Co nanoparticles. ${ }^{31,32}$ Surface functionalisation of these

40 nanoparticles can be achieved by incorporating to the surfactant mixture used during their synthesis long chain carboxylic acids functionalised at the $\omega$-position with the desired groups. ${ }^{21 \mathrm{c}}$ For this purpose we prepared bifunctional molecules that contained a carboxy group at one end (for immobilisation purposes) and a 45 crown ether (for cation binding purposes) at the other end.

For the assembly of functional cobalt nanoparticles 6a-b it was more convenient to follow a slightly modified procedure where the functional units 5a-b were prepared in a separate step, being then used as ligands for cobalt nanoparticles generated in their ${ }_{50}$ presence (Scheme 1). ${ }^{31}$ The implementation of this procedure required the prior preparation of both 11-azidoundecanoic acid ${ }^{33}$ and propargyl derivatives of crown ethers 3-4. These intermediates were then cycloadded through a well established protocol for $\mathrm{CuAAC}$ reactions, using $\mathrm{CuSO}_{4} /$ sodium ascorbate in s5 a 1:1 mixture of water and tert-butyl alcohol under microwave irradiation (see ESI). With compounds 5a-b in hand, functionalised nanoparticles $\mathbf{6} \mathbf{a}-\mathbf{b}$ were prepared (Scheme 1). In both cases, transmission electron microscopy (TEM; see Figure 2 for the case of 6a) showed the formation of regular, spherical 60 nanoparticles. Elemental analysis of the materials confirmed the presence of nitrogen containing species on the surface of the nanoparticles.
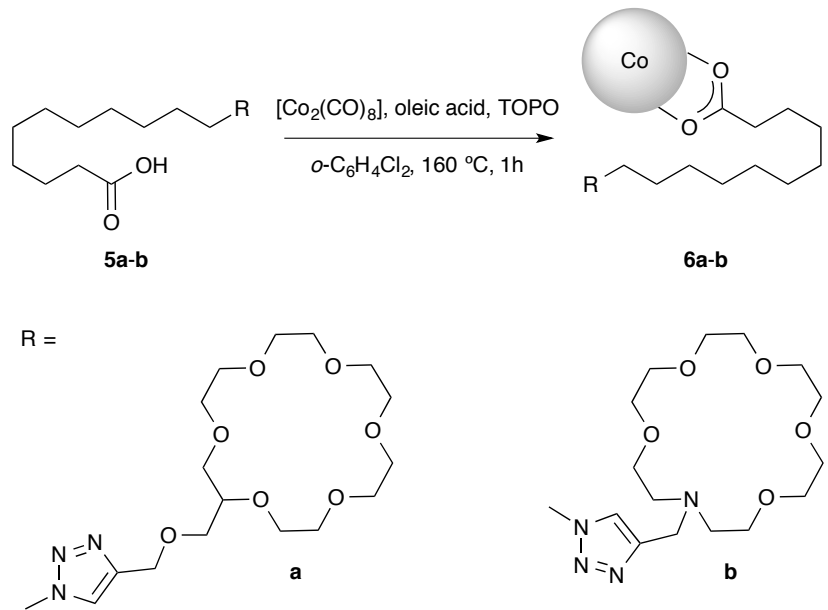

65 Scheme 1 Preparation of functionalised cobalt nanoparticles. TOPO= trioctylphosphine oxide.

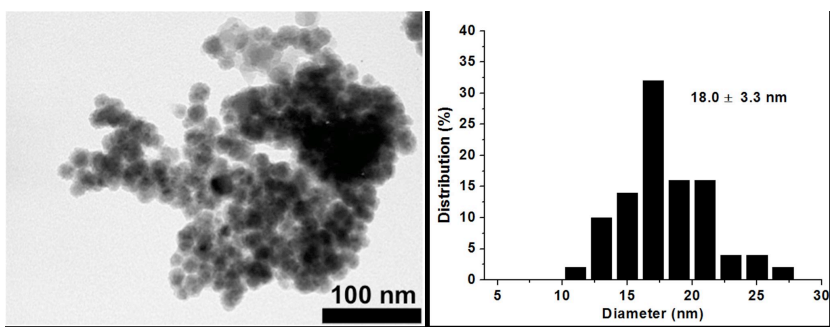

Figure 2 TEM image and size distribution of cobalt nanoparticles $\mathbf{6 a}$.

The nitrogen content $(\% \mathrm{~N})$ allowed us to calculate the degree of ligand incorporation onto the nanoparticles. The functionalisation was $0.091 \mathrm{mmol} / \mathrm{g}$ for $\mathbf{6 a}$ and $0.113 \mathrm{mmol} / \mathrm{g}$ in the case of $\mathbf{6 b}$.

\section{${ }_{75}$ Synthesis of functionalised iron oxide nanoparticles}

$\varepsilon$-Cobalt nanoparticles, although showing well-controlled shapes and allowing high levels of functionalisation, present the inconvenient of a rather cumbersome preparation: high temperatures are required to induce the decomposition of ${ }_{80}\left[\mathrm{Co}_{2}(\mathrm{CO})_{8}\right]$ and the isolated yield of nanoparticles is usually low. To avoid these difficulties the use of readily available $\mathrm{Fe}_{3} \mathrm{O}_{4}$ nanoparticles as an alternative support was pursued. To modify the surface of the iron oxide nanoparticles, a ligand exchange reaction can be used starting from the as-prepared oleic acid 
stabilised MNPs. We investigated two different types of functional agents suitable for this purpose, namely alkoxysilanes with variable chain length and phosphonic acid derivatives. $\mathrm{Fe}_{3} \mathrm{O}_{4}$ nanoparticles coated with alkoxysilanes were prepared following 5 the route shown in Scheme 2A. In the first step, oleic acid stabilised nanoparticles 7 were produced by coprecipitation of aqueous solutions of $\mathrm{Fe}^{\mathrm{II}}$ and $\mathrm{Fe}^{\mathrm{III}}$ chlorides with ammonium hydroxide, in the presence of oleic acid following a previously reported procedure. ${ }^{34}$ In this manner, fairly disperse $\mathrm{Fe}_{3} \mathrm{O}_{4}$ 10 nanoparticles of $8.4 \pm 2.6 \mathrm{~nm}$ mean diameter (Figure 3, a) were obtained (see ESI for X-ray diffraction spectrum). The presence of oleic acid on the nanoparticle surface was confirmed by IR spectroscopy (Figure 4). ${ }^{35,36} \omega$-Azidoalkyltrialkoxysilanes 8i-iii, which would be placed in the surface of the magnetite 15 nanoparticles for further functionalisation through CuAAC reactions were prepared by standard procedures (see ESI) ${ }^{37}$ Then, the functionalisation of the oleic acid stabilised nanoparticles was achieved following a ligand exchange process previously reported, ${ }^{36}$ (Scheme $2 \mathrm{~A}$, step b). In all cases 20 spherically shaped $7-10 \mathrm{~nm}$ nanoparticles were obtained as shown by TEM images (Figure 3b). The incorporation of the $\omega$ azidoalkyltrialkoxysilane in nanoparticles 9i-iii was evidenced by IR spectroscopy, through the appearance of a band at around $2097 \mathrm{~cm}^{-1}$, corresponding to the $\mathrm{N}_{3}$ asymmetric stretching and the 25 appearance of bands between $1020-1050 \mathrm{~cm}^{-1}$, due to $\mathrm{Si}-\mathrm{O}-\mathrm{Si}$ vibrations (Figure 4). ${ }^{36}$ What is more, the almost complete disappearance of the bands at $3005 \mathrm{~cm}^{-1}(=\mathrm{C}-\mathrm{H})$ and $1684 \mathrm{~cm}^{-1}$ $(\mathrm{C}=\mathrm{C})$ evidenced the effective exchange of the oleic acid ligand by the different $\omega$-azidoalkyltrialkoxysilanes. ${ }^{38}$

30 Nitrogen elemental analysis allowed the calculation of the degree of ligand incorporation onto the nanoparticles $(f=0.238[\% \mathrm{~N}])$. The determined functionalisation were $0.480 \mathrm{mmol} / \mathrm{g}$ for $9 \mathbf{i}$, $0.297 \mathrm{mmol} / \mathrm{g}$ for $9 \mathrm{ii}$, and $0.233 \mathrm{mmol} / \mathrm{g}$ for 9 iii. ${ }^{39}$ Finally, the incorporation of the cation binding units 10a and $10 \mathrm{~b}$ onto the ${ }_{35} \mathrm{MNP}$ was carried out using the CuAAC reaction in dimethylformamide (DMF), with $\mathrm{CuI}$ as catalyst in the presence of $\mathrm{N}, \mathrm{N}$-diisopropylethylamine (DIPEA). Following this procedure six new types of silane-coated iron oxide nanoparticles (11ai-iii and 11bi-iii) were prepared, incorporating two different 40 macrocycles on their surfaces and three different spacers (with 3, 5 or 11 carbon atoms) between the 1,2,3-triazole unit and the surface of the nanoparticle. The incorporation of the ion-binding units onto the nanoparticles could be easily monitored by IR spectroscopy. This showed the disappearance of the azide band at ${ }_{45} 2097 \mathrm{~cm}^{-1}$ while the presence of the macrocycles was shown by the appearance of a band at $c a .1105 \mathrm{~cm}^{-1}$, as can be seen in Figure 4 for the case of 11biii. The functional nanoparticles $\mathbf{1 1}$ were obtained as a mixture of small aggregates and discrete particles of 9 to $11 \mathrm{~nm}$ (TEM images Figure 3, c and d), no ${ }_{50}$ change in the appearence or size of the nanoparticles being observed over the CuAAC reactions. Additionally, functional nanoparticles 12 obtained by CuAAC reaction of phenylacetylene with azide nanoparticles 9i were prepared (see ESI), to evaluate any possible effect of the triazole ring on the extraction of metal 55 ions. In this case, the tris(triazolyl)methanol copper(I) chloride complex, $[\mathrm{CuCl}(\mathrm{TTM})],{ }^{40}$ was used as the catalyst to promote the CuAAC reaction. Elemental analysis $(\% \mathrm{~N})$ indicated a functionalisation of $0.32 \mathrm{mmol} / \mathrm{g}$ for the resulting MNPs.
As a preliminary step for the preparation of nanoparticles 17, 60 where binding with the functional unit takes place through interaction with a phosphonic acid group (Scheme 2B), the preparation of 11-bromoundecylphosphonic acid (14) was first required. This was achieved through a five-step sequence starting from 11-bromoundecanol (see ESI for full details). ${ }^{41}$

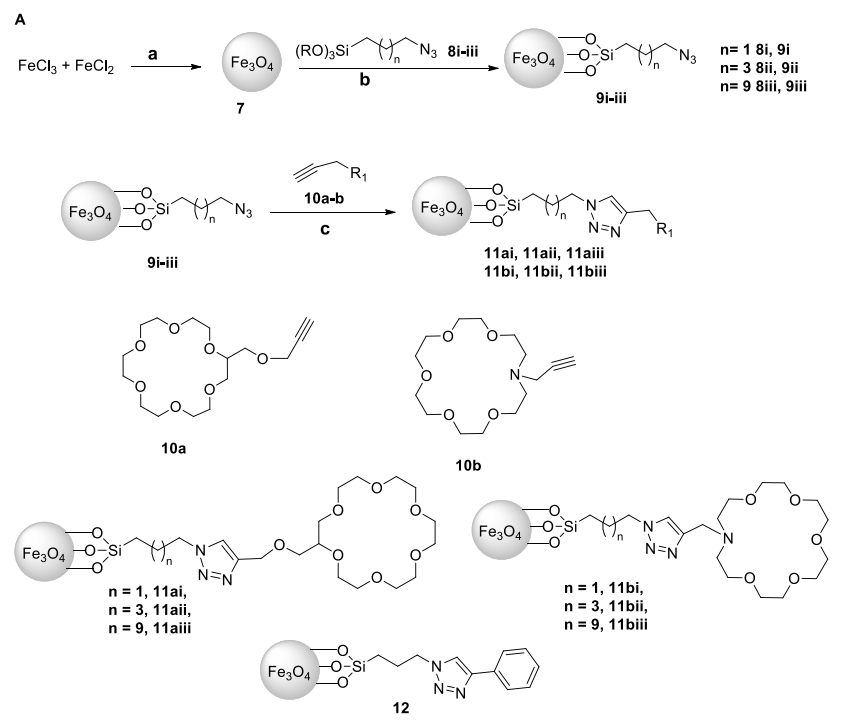

B
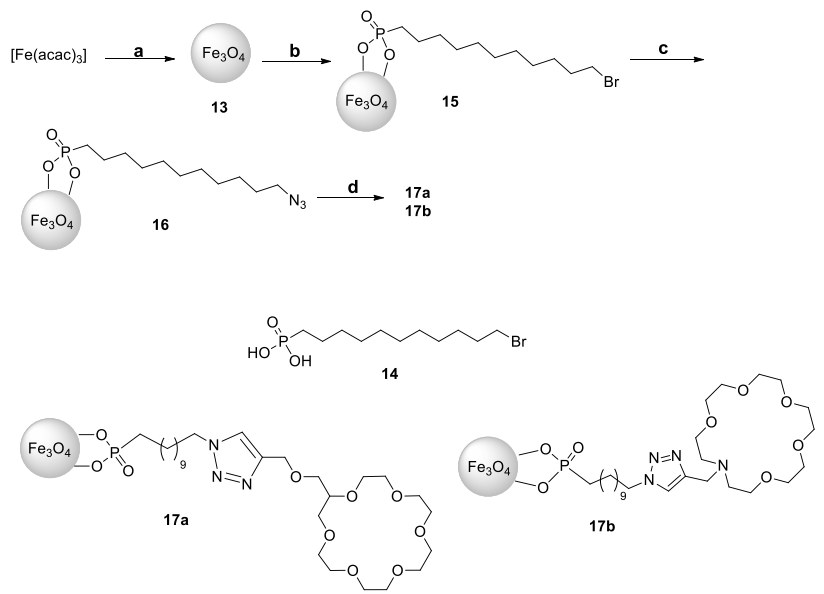

Scheme 2 A) Preparation MNPs of $\mathrm{Fe}_{3} \mathrm{O}_{4}$ functionalised with cation binding groups. Conditions: a) Oleic acid, $30 \% \mathrm{NH}_{3}, \mathrm{H}_{2} \mathrm{O}, 80^{\circ} \mathrm{C}, 30 \mathrm{~min}$; b) Acetic acid, toluene, rt, 5 days or $100^{\circ} \mathrm{C}, 24 \mathrm{~h}$; c) CuI, DIPEA, DMF, $40{ }^{\circ} \mathrm{C}$. B) Preparation of functional iron oxide nanoparticles coated with 70 phosphonic acid derivatives. Conditions: a) Oleic acid, oleylamine, 1,2hexadecanediol, benzyl ether, $200{ }^{\circ} \mathrm{C}, 2 \mathrm{~h}$, then $300{ }^{\circ} \mathrm{C}, 1 \mathrm{~h}$; b) $\mathbf{1 4}, \mathrm{CHCl}_{3}$, rt, $24 \mathrm{~h}$; c) $\mathrm{NaN}_{3}, \mathrm{DMF}, 65^{\circ} \mathrm{C}, 12 \mathrm{~h}$; d) $\mathbf{1 0 a}$ or 10b, CuI, DIPEA, DMF, $40{ }^{\circ} \mathrm{C}$.

Compound 14 was then grafted onto the surface of $6.2 \pm 2.0 \mathrm{~nm}$ 75 oleic acid/oleylamine stabilised iron oxide nanoparticles $\mathbf{1 3}$ prepared by the thermal decomposition method reported by Sun. $^{42}$ The functionalisation reaction was performed in chloroform and the incorporation of $\mathbf{1 4}$ was evidenced in the IR spectrum of MNPs 15 (Figure 5) by the appearance of very 80 intense bands in the region between 1260 and $850 \mathrm{~cm}^{-1}$ that have been assigned to P-O and P-O-Fe stretchings. ${ }^{20 a}$ The obtained nanoparticles were spherically shaped $(6.4 \pm 1.0 \mathrm{~nm})$ and well dispersed (see ESI for TEM images). The degree of ligand 
incorporation onto the nanoparticles was determined to be 2.36 $\mathrm{mmol} / \mathrm{g}$ by quantitative phosphorus determination.

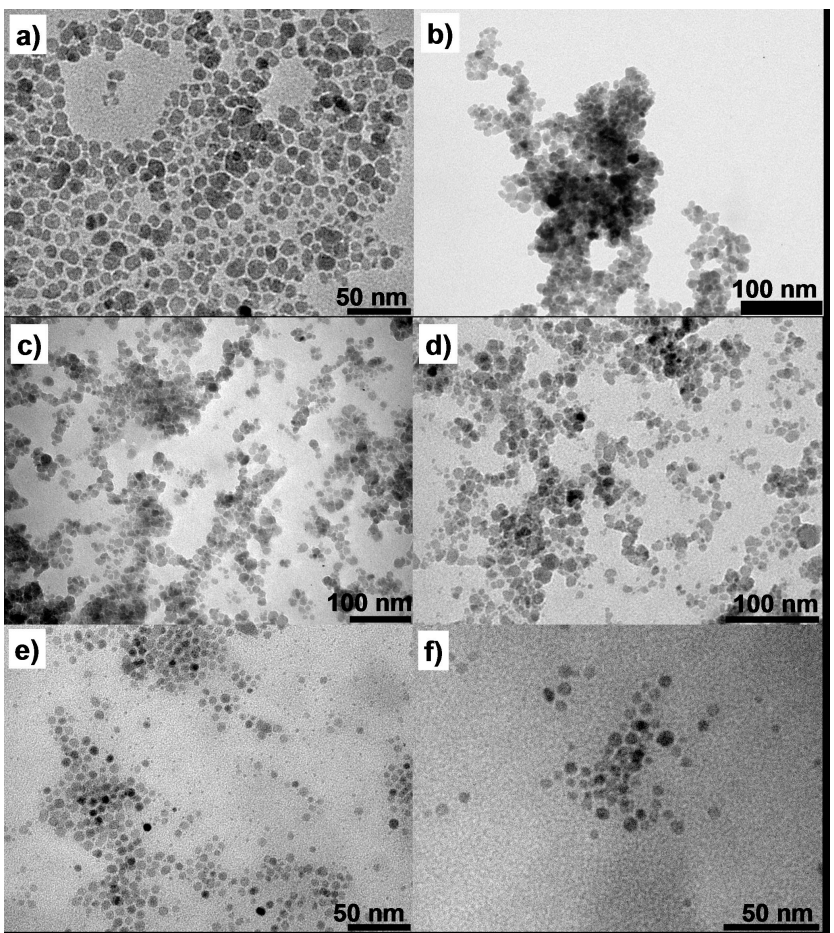

Figure 3 TEM images of a) MNPs 7, b) azide functionalised MNPs 9i, c) 5 and d) MNPs after the functionalisation with crown ethers derivatives (11ai and 11bi), e) and f) MNPs 17a and 17 b.

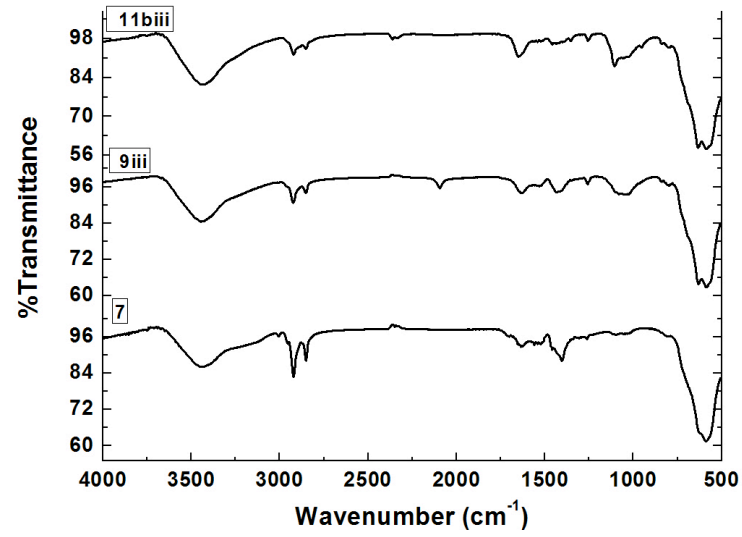

Figure 4 IR spectrum of MNPs 7, azide functionalised MNPs 9iii and MNPs after the incorporation of the azacrown ether residue (11biii).

10 Magnetic nanoparticles 15 were next transformed into the $\omega$ azidoalkylphosphonyl functionalised nanoparticles $\mathbf{1 6}(5.6 \pm 1.0$ $\mathrm{nm})$ by reaction with an excess of sodium azide in DMF at $65^{\circ} \mathrm{C}$ (Scheme 2B, step c), a transformation evidenced by the appearance of the strong $\mathrm{N}_{3}$ band in the IR spectrum (Figure 5) at $152097 \mathrm{~cm}^{-1}$. The presence of nitrogen in the surface of the nanoparticles was confirmed by elemental analysis and the degree of functionalisation of MNPs $\mathbf{1 6}$ was found to be $2.2 \mathrm{mmol} / \mathrm{g}$. For the incorporation of the metal-binding units, $\omega$ azidoalkylphosphonyl functionalised MNPs $\mathbf{1 6}$ were reacted with 20 alkynes 10a and 10b with CuI catalysis. The presence of the macrocycles in the resulting MNPs $\mathbf{1 7} \mathbf{a}-\mathbf{b}$ was evidenced by the appearance of bands at around $1100 \mathrm{~cm}^{-1}$ and $1353 \mathrm{~cm}^{-1}$ in the IR spectrum (Figure 5)

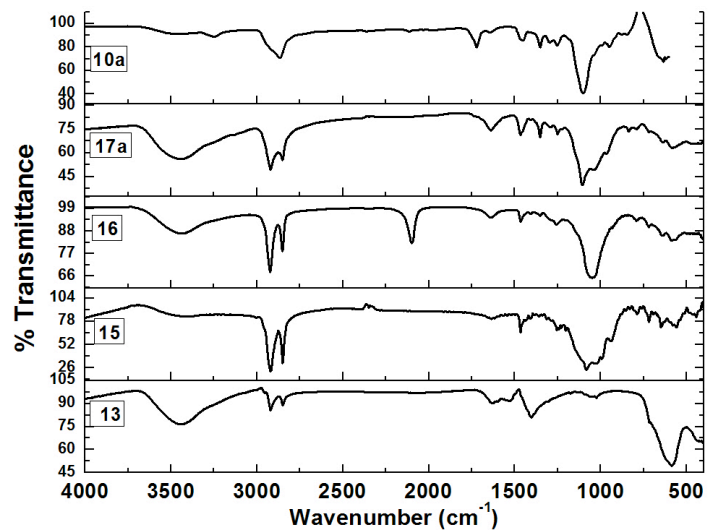

${ }_{5}$ Figure 5 IR spectrum of MNPs 13, bromo functionalised MNPs 15, azide functionalised MNPs 16 and MNPs after the incorporation of the crown ether residue (17a). For comparison the spectrum of 10a was included.

The loading of the binding units in the ready-to-act MNPs was 30 determined by elemental analysis $(\% \mathrm{~N})$, being $1.0 \mathrm{mmol} / \mathrm{g}$ for 17a and $1.27 \mathrm{mmol} / \mathrm{g}$ for $\mathbf{1 7 b}$. TEM images (Figure $3 \mathrm{e}$ and $3 \mathrm{f}$ ) indicated that the macrocycle-functionalised nanoparticles had a narrow size distribution, with average diameters of about $6.0 \mathrm{~nm}$. Moreover there was no change neither in size nor in the spherical ${ }_{35}$ shape of the nanoparticles during the functionalisation reactions.

\section{Preparation of functionalised polystyrene and polystyrene- polyethyleneglycol resins.}

(Azidomethyl)polystyrene (18) and (2-azidoethoxy)polystyrene40 polyethyleneglycol (19) were prepared by reaction of the corresponding halogenated commercial resins with sodium azide following previously reported procedures. ${ }^{17 \mathrm{~b}, 17 \mathrm{~d}}$ Alkynes 10a and 10b were reacted with the azide-functionalised polymers using $\mathrm{CuI} / \mathrm{DIPEA}$ as catalyst and a 1:1 DMF/THF mixture as solvent ${ }_{45}$ (Scheme 3). The completeness of the reaction was established by IR spectroscopy, in a similar fashion as with the iron oxide nanoparticles (see above). The obtained resins 20a-b and 21a-b have extractant loadings of around $0.2 \mathrm{mmol} / \mathrm{g}$ for the PS-PEG polymers and around $0.6 \mathrm{mmol} / \mathrm{g}$ for the PS resins (determined ${ }_{50}$ by nitrogen elemental analysis). These functionalisations accurately reflect those of the starting commercial resins (see ESI). To evaluate any possible contribution of the triazole unit to the extraction of metal ions, functional PS-PEG resin 22 was also prepared by $\mathrm{CuAAC}$ reaction with phenylacetylene. 


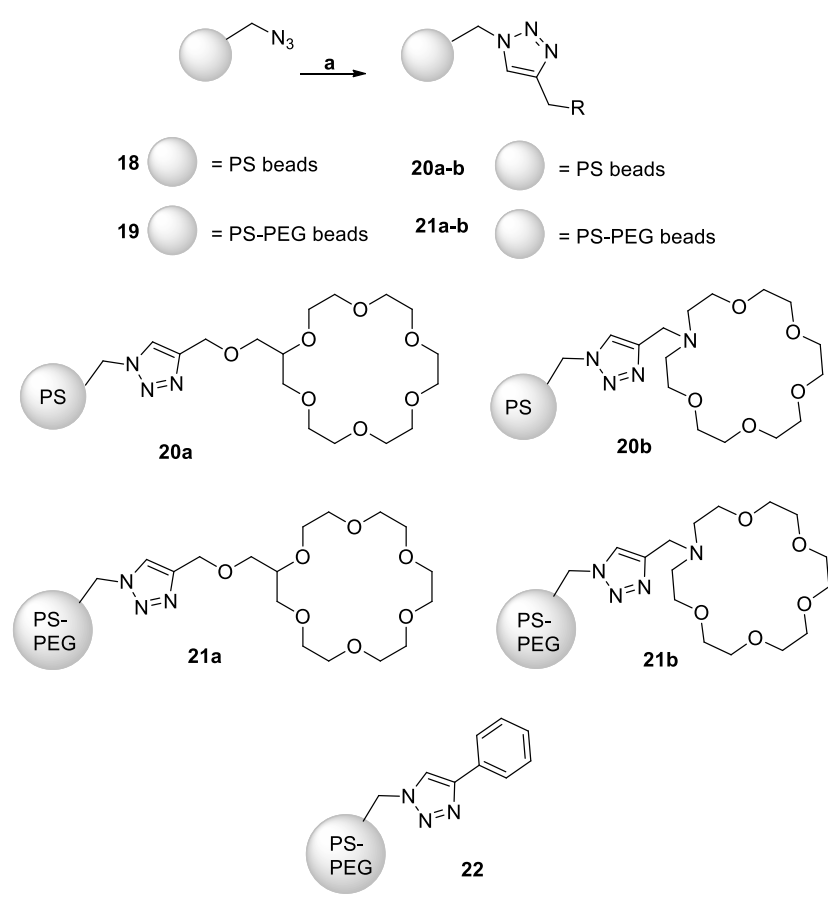

Scheme 3 Preparation of crown ether-functionalised polymers Conditions: a) 10a or 10b, CuI, DIPEA, 1:1 DMF/THF, $40^{\circ} \mathrm{C}, 1-5$ days.

\section{Metal extraction experiments}

Once the different types of extracting materials were prepared and fully characterised, their ability to extract metal ions from aqueous and organic solutions was evaluated. The main goal of 10 these studies was the identification of optimal combinations of support and complexing agent for specific situations (solvent nature, $\mathrm{pH}$ of aqueous solutions), and also determining the influence of additional factors (immobilization strategy, complexing unit loading) on the performance of these 15 combinations. To perform these studies, the extraction of $\mathrm{Pb}^{2+}$ from aqueous and organic solutions was selected as a representative and yet not fully solved case. ${ }^{43}$

\section{Extraction with MNPs}

20

The metal extracting capability of the nanoparticles was investigated by placing the extracting material in contact with either aqueous or acetonitrile solutions of $\mathrm{Pb}\left(\mathrm{ClO}_{4}\right)_{2}$ of known concentration $\left([\mathrm{Pb}]_{\text {initial }}\right)$. The samples were shacken in a closed

${ }_{25}$ flask for the specified period of time, and then the nanoparticles were separated with the help of an external magnet. The resulting clear solution was analysed to determine the final concentration of $\mathrm{Pb}^{2+}\left([\mathrm{Pb}]_{\text {final }}\right)$. Both concentrations of $\mathrm{Pb}^{2+}$ were determined by flame atomic absorption spectroscopy (FAAS). The amount of 30 lead that was extracted from the solution by the nanoparticles was calculated according to equation 1 .

$$
\% \mathrm{~Pb} \text { extracted }=100 \times\left([\mathrm{Pb}]_{\text {initial }}-[\mathrm{Pb}]_{\text {final }}\right) /[\mathrm{Pb}]_{\text {initial }}
$$

35 Table 1 shows the results for the removal of $\mathrm{Pb}^{2+}$ from acetonitrile solutions, using functionalised cobalt and iron oxide nanoparticles. Extractant 6a, functionalised with a 18-crown-6 ether was first tested. Interestingly, up to $79 \%$ of the initially present cation was removed from solution (entry 1). In a similar 40 manner, a significant amount of $\mathrm{Pb}^{2+}$ was also removed form the solution using extractant $\mathbf{6 b}$ (entry 2).

Functionalised iron oxide nanoparticles were also employed in the removal of $\mathrm{Pb}^{2+}$ from acetonitrile solutions. Also in this case, the nanoparticles are able to bind and remove $\mathrm{Pb}^{2+}$ from the 45 solution (entries 3 and 4, Table 1). However the extracted percentages are much smaller than in the case of cobalt nanoparticles. In particular, for the case of $\mathbf{1 1 b i}$, just $10 \%$ of the $\mathrm{Pb}^{2+}$ was removed because the nanoparticles were dissolved in the solution, and could not be separated by the external magnetic so field.

Table 1 Extraction of $\mathrm{Pb}^{2+}$ from $\mathrm{CH}_{3} \mathrm{CN}$ solutions using functionalised $\mathrm{Co}$ and $\mathrm{Fe}_{3} \mathrm{O}_{4}$ nanoparticles.

\begin{tabular}{|c|c|c|c|c|c|}
\hline & Entry & Extractant & $\begin{array}{c}\text { Extractant } \\
\text { to } \mathrm{Pb}^{2+} \\
\text { ratio }\end{array}$ & $\begin{array}{l}\text { Contact } \\
\text { time } / \mathrm{h}\end{array}$ & $\begin{array}{l}\% \mathrm{~Pb} \\
\text { extracted }^{\mathrm{a}}\end{array}$ \\
\hline \multirow{2}{*}{$\begin{array}{c}\text { Functionalised } \\
\varepsilon \text {-Cobalt } \\
\text { nanoparticles } \\
\end{array}$} & 1 & $6 a$ & $1: 1$ & 21 & $79(1)$ \\
\hline & 2 & $6 b$ & $1: 1$ & 21 & $68(1)$ \\
\hline \multirow{2}{*}{$\begin{array}{c}\text { Functionalised } \\
\mathrm{Fe}_{3} \mathrm{O}_{4} \\
\text { nanoparticles }\end{array}$} & 3 & 11ai & $1: 1$ & 21 & $47(1)$ \\
\hline & 4 & $11 b i^{b}$ & $1.5: 1$ & 21 & $10(1)$ \\
\hline
\end{tabular}

In view of the promising results obtained in the removal of lead cation from acetonitrile solutions, we decided to test the 60 behaviour of our systems in aqueous media. Table 2 shows data of the extracting experiments using functional iron oxide MNPs, in the removal of $\mathrm{Pb}^{2+}$ from aqueous solutions.

Table 2 Extraction of $\mathrm{Pb}^{2+}$ form aqueous solutions using functionalised $65 \mathrm{Fe}_{3} \mathrm{O}_{4}$ nanoparticles.

\begin{tabular}{ccccc}
\hline Entry & Extractant & $\begin{array}{c}\text { Contact } \\
\text { time } / \mathrm{h}\end{array}$ & $\begin{array}{c}\text { Extractant to } \mathrm{Pb}^{2+} \\
\text { ratio }\end{array}$ & $\begin{array}{c}\text { \% } \mathrm{Pb}^{2+} \\
\text { extracted }^{\mathrm{a}}\end{array}$ \\
\hline 1 & $\mathbf{1 1 a i}$ & 41 & $1: 1$ & $29(1)$ \\
2 & $\mathbf{1 1 b i}$ & 41 & $1: 1$ & $21(1)$ \\
3 & $\mathbf{1 1 a i i}$ & 41 & $1: 1$ & $45(4)$ \\
4 & $\mathbf{1 1 b i i}$ & 41 & $1: 1$ & $30(6)$ \\
5 & $\mathbf{1 1 a i i}$ & 41 & $2: 1$ & $66(3)$ \\
6 & $\mathbf{1 1 a i i i}$ & 41 & $1: 1$ & $53(5)$ \\
7 & $\mathbf{1 1 b i i i}$ & 41 & $1: 1$ & $62(1)$ \\
8 & $\mathbf{9 i}$ & 41 & $1.5: 1$ & $2(1)$ \\
9 & $\mathbf{1 2}$ & 41 & $2: 1$ & $14(1)$ \\
10 & $\mathbf{1 7 a}$ & 21 & $1: 1$ & $49(4)$ \\
11 & $\mathbf{1 7 b}$ & 21 & 1.1 & $38(2)$ \\
12 & $\mathbf{1 7 a}$ & 21 & $2.8: 1$ & $92(2)$ \\
13 & $\mathbf{1 7 a}$ & 41 & $2.6: 1$ & $86(4)$ \\
\hline
\end{tabular}

${ }^{a}$ Mean values of two independent determinations. Observed result variability is given in parentheses.

Using an equimolar amount of extracting groups and metal 70 cations in solution, between $21 \%$ to $62 \%$ of the $\mathrm{Pb}$ can be removed from the aqueous solution in a single operation. The nanoparticles containing the 18 -crown- 6 moiety in combination 
with the shorter, more readily available spacers ( $n=1$ and 3 ) allow higher extraction percentages than those bearing monoaza18-crown-6 units. In general, as the chain length increases a slightly positive effect on the extraction values is noted 5 independently of the nature of the extracting unit. In order to secure that the extracting power of these materials arises from the binding units present in their structures, control experiment were performed with MNPs $9 \mathbf{i}(<2 \%$, entry 8$)$ and $\mathbf{1 2}(14 \%$, entry 9$)$. This last result seems to indicate that the triazole group can 10 contribute to some extent to the extraction of lead cations from the aqueous solution. As we will see later, this impression is not confirmed by the results obtained with the same complexing agents clicked on polymers. Functional nanoparticles 17a and $\mathbf{1 7} \mathbf{b}$, where the functional unit is bonded to the magnetic core 15 through a phosphonate unit, were also used in the extraction experiments from aqueous solution. The experiments were performed in a similar manner as with MNPs 11, and the results are also shown in Table 2 (entries 10-13). Again, 18-crown-6 functionalised nanoparticles seem to be more effective than 20 monoaza-18-crown-6 in removing lead from the solutions achieving nearly a $49 \%$ of removal with 17 a. Interestingly, when a 2.8:1 ratio of extractant was used, $92 \%$ of the initially present metal loading was removed from the solution in a single extraction (entry 12).

25 Table 3 Effect of the amount of extractant in the removal of $\mathrm{Pb}^{2+}$ form aqueous solutions using MNPs of $\mathrm{Fe}_{3} \mathrm{O}_{4}$

\begin{tabular}{ccccc}
\hline Entry & Extractant & $\begin{array}{c}\text { Contact } \\
\text { time } / \mathrm{h}\end{array}$ & $\begin{array}{c}\text { Extractant to } \mathrm{Pb}^{2+} \\
\text { ratio }\end{array}$ & $\begin{array}{c}\% \mathrm{~Pb}^{2+} \\
\text { extracted }\end{array}$ \\
\hline 1 & 11ai & 41 & $1: 1$ & $29(1)$ \\
2 & 11ai & 41 & $2: 1$ & $38(1)$ \\
3 & 11ai & 41 & $4: 1$ & $61(2)$ \\
4 & 11ai & 41 & $10: 1$ & $91(2)$ \\
\hline
\end{tabular}

${ }^{\mathrm{a}}$ Mean values of two independent determinations. Observed result variability is given in parentheses.

With the goal of determining conditions for the extraction of ${ }_{30}>90 \%$ of the initially present $\mathrm{Pb}^{2+}$ in a single operation using the more readily available MNPs 11ai, a set of experiments was performed using increasing amounts of this extractant (Table 3). As it can be seen, a $91 \%$ of the initially present lead was removed from the solution in a single treatment when a 10:1 extractant to 35 metal ratio was used.

\section{Extraction with functional polymers}

Functional polymers 20a and 20b were also used for the selective 40 removal of lead from organic solvents. THF was chosen as solvent, because it was adequate for the swelling of the polymers. Results of the extraction experiments are shown in Table 4.

Table 4 Extraction of $\mathrm{Pb}^{2+}$ from THF solutions, using functional ${ }^{45}$ polystyrene resins.

\begin{tabular}{ccccc}
\hline Entry & Extractant & $\begin{array}{c}\text { Extractant } \\
\mathrm{Pb}^{2+} \text { ratio }\end{array}$ & $\begin{array}{c}\text { Contact } \\
\text { time } / \mathrm{h}\end{array}$ & $\begin{array}{c}\% \mathrm{~Pb} \\
\text { extracted }^{\mathrm{a}}\end{array}$ \\
\hline 1 & $\mathbf{2 0 a}$ & $1: 1$ & 24 & $91(2)$ \\
2 & $\mathbf{2 0 b}$ & $1: 1$ & 24 & $86(3)$ \\
3 & $\mathbf{1 8}$ & $2: 1$ & 24 & 0 \\
\hline
\end{tabular}

${ }^{a}$ Mean values of two independent determinations. Observed result variability is given in parentheses.
As it can be seen, high extraction percentages, of around 90\% 50 were achieved with polystyrene-immobilised complexing agents 20a-b. To show that there was no unspecific binding to the resin, the extraction experiment was also carried out using polymer 18, and, no decrease in the amount of $\mathrm{Pb}$ in the solution being observed (entry 3 ).

${ }_{55}$ Resins 20b and 21a-b were also tested for extraction from water (Table 5). Polystyrene resin $\mathbf{2 0 b}$ was inefficient under these conditions (entry 1), likely because of poor swelling. Amphiphilic resins 21a and 21b performed much better with respect to swelling in water, and its extracting potential was studied at ${ }_{60}$ different $\mathrm{pH}$ values. Using resin 21b a $43 \%$ of extraction was achieved in water under neutral conditions, while in acidic media (pH 1 and $\mathrm{pH} 3$ ) the extraction capacity was highly reduced due to the protonation of the tertiary amine in the monoaza-18-crown6 moiety. Resin 21a works poorly in water at $\mathrm{pH}=7$ (14\%), but ${ }_{65}$ its extraction ability was improved at $\mathrm{pH} 1$ (45\%). Again, control experiments were performed using azido resin 19 (entry 13) and phenyltriazole functionalised resin 22 (entry 14). No decrease in the amount of $\mathrm{Pb}$ was observed in any of the cases. The result in entry 14 indicates that, at least in this case, the presence of the 70 triazole group does not contribute to any extent to the binding of cations, in contrast with what we observed for the case of magnetite nanoparticles (see above). As observed for the extraction with functional MNPs, increasing the amount functional resin used as extractant allows increasing the removal 75 of lead up to $72 \%$ in a single operation (entry 11 ).

Table 5 Extraction of $\mathrm{Pb}^{2+}$ using functionalised PS-PEG in water at different $\mathrm{pH}$

\begin{tabular}{cccccc}
\hline Entry & Extractant & $\begin{array}{c}\text { Extractant to } \\
\mathrm{Pb}^{2+} \text { ratio }\end{array}$ & $\begin{array}{c}\text { Solvent } \\
(\mathrm{pH})^{\mathrm{a}}\end{array}$ & $\begin{array}{c}\text { Contact } \\
\text { time/h }\end{array}$ & $\begin{array}{c}\text { \% Pb } \\
\text { extracted }\end{array}$ \\
\hline 1 & 20b & $2: 1$ & $\mathrm{H}_{2} \mathrm{O}^{\mathrm{b}}$ & 41 & $14(1)$ \\
2 & 21b & $1: 1$ & $\mathrm{H}_{2} \mathrm{O}^{\mathrm{b}}$ & 24 & $43(3)$ \\
3 & 21b & $1: 1$ & $\mathrm{H}_{2} \mathrm{O}(1)$ & 24 & 0 \\
4 & 21b & $1: 1$ & $\mathrm{H}_{2} \mathrm{O}(3)$ & 24 & 0 \\
5 & 21b & $1: 1$ & $\mathrm{H}_{2} \mathrm{O}^{\mathrm{b}}$ & 16 & $37(2)$ \\
6 & 21b & $1: 1$ & $\mathrm{H}_{2} \mathrm{O}^{\mathrm{b}}$ & 41 & $43(1)$ \\
7 & 21b & $2: 1$ & $\mathrm{H}_{2} \mathrm{O}^{\mathrm{b}}$ & 24 & $60(1)$ \\
8 & 21a & $1: 1$ & $\mathrm{H}_{2} \mathrm{O}^{\mathrm{b}}$ & 24 & $14(1)$ \\
9 & 21a & $1: 1$ & $\mathrm{H}_{2} \mathrm{O}(1)$ & 24 & $45(3)$ \\
10 & 21a & $2.6: 1$ & $\mathrm{H}_{2} \mathrm{O}(1)$ & 24 & $59(2)$ \\
11 & 21a & $4.5: 1$ & $\mathrm{H}_{2} \mathrm{O}(1)$ & 24 & $72(2)$ \\
12 & 21a & $1: 1$ & $\mathrm{H}_{2} \mathrm{O}(3)$ & 24 & $6(2)$ \\
13 & 19 & $1: 1$ & $\mathrm{H}_{2} \mathrm{O}^{\mathrm{b}}$ & 24 & 0 \\
14 & 22 & $1: 1$ & $\mathrm{H}_{2} \mathrm{O}^{\mathrm{b}}$ & 24 & 0 \\
\hline
\end{tabular}

${ }^{\mathrm{a}}$ The corresponding $\mathrm{pH}$ values are given in parentheses. ${ }^{\mathrm{b}}$ Pure water, $\mathrm{pH}=$ 807 . ' Mean values of two independent determinations. Observed result variability is given in parentheses.

\section{Experimental}

\section{General information}

Unless otherwise stated, all commercial compounds were used as 85 received without any further purification. Ultra pure water was obtained from an SG Water Ultra clear basic system, that provides water with a conductivity at $25{ }^{\circ} \mathrm{C}$ of $0.055 \mu \mathrm{S}$. Dry solvents $\left(\mathrm{CH}_{2} \mathrm{Cl}_{2}\right.$, THF, DMF, diethyl ether, hexane and toluene) were obtained from a Puresolv ${ }^{\mathrm{TM}}$ purification system. Dry $o$ 90 dichlorobenzene and methanol were obtained by treatment with 
pellets of $4 \AA$ molecular sieves (previously activated by microwave irradiation) under argon atmosphere. When degassed solvents were required, an argon stream was passed through the solvent. IR spectra of nanoparticles were recorded on a Bruker 5 Tensor 27 FTIR spectrophotometer or in a Thermo Nicolet 5700 FTIR spectrometer, using $\mathrm{KBr}$ pellets. ${ }^{1} \mathrm{H}$ and ${ }^{13} \mathrm{C}$ experiments of polymers were performed with a Bruker Avance spectrometer operating at a frequency of $500.13 \mathrm{MHz}$ using a Bruker $4 \mathrm{~mm}$ ${ }^{1} \mathrm{H} /{ }^{13} \mathrm{C} /{ }^{2} \mathrm{H}$ gradient HR-MAS probe. Transmission electron 10 microscopy (TEM) images were obtained with a JEOL JEM-1011 transmission electron microscope equipped with a lanthanum hexaboride filament operated at an acceleration voltage of 100 $\mathrm{kV}$. Flame atomic absorption measurements were performed in a Hitachi Polarized Zeeman Atomic Absorption Spectrometer. All 15 the glassware used in the metal extraction experiments was previously treated overnight with $20 \% \mathrm{v} / \mathrm{v} \mathrm{HNO}_{3}$ and rinsed with ultra pure water. The solutions for the metal extraction experiments were prepared using ultra pure water. Reactions heated under microwave irradiation were performed in a CEM

20 Discover microwave synthesis apparatus using $10 \mathrm{~mL}$ vessels with septa for reactions performed at elevated temperatures and pressures. Phosphorus content determinations were performed by Inductively Coupled Plasma Atomic Emmision Spectroscopy (ICP-AES) at the Service Central d'Analyse of the Centre ${ }_{25}$ National de la Recherche Scientifique (France).

Preparation and functionalisation of cobalt nanoparticles for extraction of metals

\section{Typical procedure for the preparation of cobalt nanoparticles functionalised with crown ether derivatives: Preparation of functional nanoparticles $6 \mathrm{a}$}

These nanoparticles were prepared by slight modifications of a 35 previously reported procedure. ${ }^{21 \mathrm{c}, 31}$ Crown ether derivative 5a $(0.29 \mathrm{~g}, 0.529 \mathrm{mmol})$ and trioctylphosphine oxide (TOPO) $>97 \%$ $(0.042 \mathrm{~g}, 0.0363 \mathrm{mmol})$ were weighed in a $50 \mathrm{~mL}$ two-necked round-bottomed flask and dissolved under an argon atmosphere in $6 \mathrm{~mL}$ of anhydrous and degassed $o$-dichlorobenzene. To this 40 suspension, $85.5 \mu \mathrm{L}$ of oleic acid 98\% (0.0762 g, $0.2644 \mathrm{mmol})$ were injected and the mixture was heated in a silicone oil bath at $160{ }^{\circ} \mathrm{C}$, with mechanical stirring using a shaker. When the bath had reached the desired temperature, a solution of $0.201 \mathrm{~g}(0.529$ $\mathrm{mmol})$ of $\left[\mathrm{Co}_{2}(\mathrm{CO})_{8}\right](\geq 90 \%)$ in $5 \mathrm{~mL}$ of anhydrous, degassed, $45 O$-dichlorobenzene was rapidly transferred into the reaction media by injection. The reaction mixture was mechanically stirred at $160{ }^{\circ} \mathrm{C}$ for 1 hour. After cooling to room temperature, $24 \mathrm{~mL}$ of anhydrous and degassed methanol were added. The resulting suspension was stored in the freezer under argon until the

50 precipitation of the particles ( 3 hours). The particles were separated by magnetic decantation and washed once with anhydrous, degassed methanol $(20 \mathrm{~mL})$ and with anhydrous, degassed dichloromethane $(40 \mathrm{~mL})$ The solvents were removed in vacuo and the residual solid was dried under a nitrogen stream. In 55 this manner, $35.3 \mathrm{mg}$ of cobalt nanoparticles $\mathbf{6 a}$ were obtained with particle size of $18 \mathrm{~nm}(s=3.3)$ and $f=0.091 \mathrm{mmol} / \mathrm{g}$. Elemental analysis: C, 5.81; H, 0.84; N, 0.38. FTIR $v_{\max } / \mathrm{cm}^{-1}$ $3443,2958,2922,2853,1620,1460,1413,1225,1101,801,524$,
457.

60

Preparation and functionalisation of magnetite nanoparticles

Typical procedure for the preparation of magnetite nanoparticles coated with oleic acid (7)

These nanoparticles were prepared by slight modifications of a previously reported procedure. ${ }^{34}$ Iron(II) chloride tetrahydrate (99\%) (3.01 g, $15 \mathrm{mmol}$ ) and iron(III) chloride hexahydrate (97\%) (8.36 g, $30.0 \mathrm{mmol})$ were dissolved in degassed ultra pure 70 water $(140 \mathrm{~mL})$ in a $500 \mathrm{~mL}$ round-bottomed flask and heated to $80{ }^{\circ} \mathrm{C}$, shaking vigorously with a shaker. Oleic acid (98\%) (2.1 mmol, $0.60 \mathrm{~g}, 0.68 \mathrm{~mL})$ dissolved in degassed acetone $(15 \mathrm{~mL})$ was added to the reaction mixture, followed by $30 \%$ aqueous $\mathrm{NH}_{3}$ solution $(18.2 \mathrm{~mL})$. After addition, further amounts of oleic 75 acid were added $(5 \times 1.0 \mathrm{~mL})$ over a 5 to 10 minutes period. The black reaction mixture was hold for 30 minutes at $80^{\circ} \mathrm{C}$ and then slowly cooled to room temperature. A $1: 1 \mathrm{v} / \mathrm{v}$ mixture of methanol and acetone $(100 \mathrm{~mL})$ was then added to support the precipitation. After allowing the nanoparticles to settle overnight 80 with the help of a magnet, the supernatant was separated using a cannula and the particles were washed with a $1: 1 \mathrm{v} / \mathrm{v}$ mixture of methanol and acetone $(5 \times 100 \mathrm{~mL})$. The nanoparticles were dried, first with an argon stream and then under vacuum. In this manner, $3.8 \mathrm{~g}$ of nanoparticles were isolated as a dark brown 85 solid with a particle size of $8.40 \mathrm{~nm}(s=2.56)$. FTIR $v_{\max } / \mathrm{cm}^{-1}$ 3453, 3005, 2956, 2923, 2852, 1632, 1426, 1409, 1261, 1229, $1100,1056,802,580$. TGA $\left(30-1000^{\circ} \mathrm{C}, 10^{\circ} \mathrm{C} / \mathrm{min}, \mathrm{N}_{2}\right) \%$ weight loss (onset $\left.\left[{ }^{\circ} \mathrm{C}\right]\right): 6.89$ (306.64), 6.71 (663.09).

90 Typical procedure for the preparation of magnetite nanoparticles coated with oleic acid (13)

These nanoparticles were prepared by slight modifications of a previously reported procedure. ${ }^{42}$ Iron(III) acetylacetonate $98 \%$ 95 (0.706 g, $1.96 \mathrm{mmol})$, oleic acid (1.9 mL, $5.99 \mathrm{mmol})$ oleylamine (1.60 g, $1.93 \mathrm{~mL}, 5.99 \mathrm{mmol})$ and 1,2-hexadecanediol 90\% (2.58 $\mathrm{g}, 8.98 \mathrm{mmol}$ ) were mixed in $20 \mathrm{~mL}$ of benzyl ether $99 \%$ under nitrogen. The mixture was heated at $200{ }^{\circ} \mathrm{C}$ for 2 hours and then at $300{ }^{\circ} \mathrm{C}$ for one more hour. The mixture was then allowed to 100 cool down to room temperature and $40 \mathrm{~mL}$ of ethanol were added. Centrifugation allowed the separation of a dark-brown solid that was dissolved in hexane $(5 \mathrm{~mL})$ and reprecipitated by addition of $40 \mathrm{~mL}$ of ethanol. The nanoparticles were obtained as a black solid $(80 \mathrm{mg})$ with a particle size of $6.18 \mathrm{~nm}(s=1.98)$. ${ }_{105}$ FTIR $v_{\max } / \mathrm{cm}^{-1} 3440,2955,2920,2850,1630,1594,1524,1401$, 585. TGA (30-900 ${ }^{\circ} \mathrm{C}, 10^{\circ} \mathrm{C} / \mathrm{min}, \mathrm{N}_{2}$ ) \%weight loss (onset $\left[{ }^{\circ} \mathrm{C}\right]$ ): 17.23 (293.49), 8.57 (634.07).

Typical procedure for the preparation of azido-magnetite 110 nanoparticles: Synthesis of functional nanoparticles 9i

These nanoparticles were prepared by slight modifications of a previously reported procedure. ${ }^{36}$ Nanoparticles 7 (0.96 g) were dispersed by sonication (20 minutes) in about $480 \mathrm{~mL}$ of 115 degassed toluene and then 3-azidopropyltrimethoxysilane $8 \mathbf{8 i}$ (1.92 g, $9.33 \mathrm{mmol}$ ) was added, followed by glacial acetic acid $99.5 \%$, 
$d=1.05 \mathrm{~g} / \mathrm{mL}(0.192 \mathrm{~mL}, 3.36 \mathrm{mmol})$ and ultrapure water $(0.269$ $\mathrm{mL}, 14.93 \mathrm{mmol})$. The reaction mixture was stirred at room temperature for 3.5 days. The black particles were allowed to settle overnight with the help of an external magnet. The 5 supernatant was separated using a cannula, and the nanoparticles were washed with toluene $(3 \times 42 \mathrm{~mL})$ and methanol $(3 \times 26 \mathrm{~mL})$ and dried under vacuum. In this manner, $0.78 \mathrm{~g}$ of nanoparticles were recovered as a brown powder with a particle size of $8.83 \mathrm{~nm}$ $(s=3.01)$ and $f=0.35 \mathrm{mmol} / \mathrm{g}$. Elemental analysis: $\mathrm{C}, 3.61 ; \mathrm{H}$, ${ }_{10} 0.80 ; \mathrm{N}, 1.48$. FTIR $v_{\max } / \mathrm{cm}^{-1} 3442,2955,2924,2852,2098\left(\mathrm{~N}_{3}\right)$, $1637,1420,1239,1182,1103,1022,585$. TGA $\left(30-1000^{\circ} \mathrm{C}, 10\right.$ ${ }^{\circ} \mathrm{C} / \mathrm{min}, \mathrm{N}_{2}$ ) \%weight loss (onset $\left[{ }^{\circ} \mathrm{C}\right]$ ): 9.79 (244.01), 4.58 (633.10).

15 Typical preparation of MNPs functionalised with crown ether: Synthesis of functional nanoparticles 11ai

Magnetite nanoparticles $9 \mathbf{i}(90 \mathrm{mg}, f=0.480 \mathrm{mmol}$ of ligand $/ \mathrm{g})$ were dispersed in $5 \mathrm{~mL}$ of anhydrous DMF in a Schlenk flask 20 under argon, using ultrasonication for $15 \mathrm{~min}$ to ensure dispersion. The alkyne 10a (43 mg, $0.13 \mathrm{mmol}$ ), dissolved in 1 $\mathrm{mL}$ anhydrous DMF was then added to the reaction media, followed by DIPEA $99.5 \%(0.136 \mathrm{~mL}, 0.78 \mathrm{mmol})$, and finally $\mathrm{CuI}(3.3 \mathrm{mg}, 0.017 \mathrm{mmol})$ as a solid. The reaction mixture was ${ }_{25}$ stirred at $40{ }^{\circ} \mathrm{C}$ under argon and the reaction progress was followed by IR spectroscopy. Once the IR bands associated to $\mathrm{N}_{3}$ had disappeared (2-10 days) the reaction was cooled to room temperature, methanol was added (c.a. $50 \mathrm{~mL}$ ), and the mixture was left overnight in the freezer. The precipitating particles were 30 separated by magnetic decantation. The supernatant was discarded and the particles were washed with methanol $(3 \times 10$ $\mathrm{mL}$ ) using centrifugation to separate the solvent. The solid material was dried with an argon stream and then in vacuo. In this manner $68.1 \mathrm{mg}$ of functional magnetite nanoparticles were 35 obtained as a brown solid, with a particle size of $10.88 \mathrm{~nm}(s=$ 3.97 ) and $f=0.343 \mathrm{mmol} / \mathrm{g}$. Elemental analysis: $\mathrm{C}, 8.88 ; \mathrm{N}, 1.47$; H, 1.44. FTIR $v_{\max } / \mathrm{cm}^{-1} 3405,2919,1726,1629,1454,1350$, $1248,1103,835,584$.

\section{${ }_{40}$ Magnetite nanoparticles stabilised by 11- bromoundecylphosphonic acid (15)}

Compound $14(0.235 \mathrm{~g}, 0.75 \mathrm{mmol})$ and $0.111 \mathrm{~g}$ of magnetite nanoparticles 13 were shacken in $15 \mathrm{~mL}$ of $\mathrm{CHCl}_{3}$ at room 45 temperature for 24 hours. Then the nanoparticles were collected using an external magnet and the organic solution was removed. The nanoparticles were washed 3 times with ethanol sonicating each time to ensure total abstraction of ligands in excess. The product was obtained as a brown solid $(0.40 \mathrm{~g})$, with a particle ${ }_{50}$ size of $6.37 \mathrm{~nm}(s=0.97)$. According to the \%P determined by ICP-AES, a functionalisation $f=2.36 \mathrm{mmol} / \mathrm{g}$ was calculated. Elemental analysis: C, 31.97; H, 5.66; N, 0.10; P, 7.32. FTIR $v_{\max } / \mathrm{cm}^{-1} 2917,2850,1466,1082,940,559$.

\section{${ }_{55}$ Magnetite nanoparticles stabilised by 11- azidoundecylphosphonic acid (16)}

To a dispersion of $15(0.13 \mathrm{~g}, 0.31 \mathrm{mmol}, f=2.36 \mathrm{mmol} / \mathrm{g})$ in 4 $\mathrm{mL}$ of DMF, $\mathrm{NaN}_{3} 95.5 \%$ (0.15 g, $\left.2.3 \mathrm{mmol}\right)$ was added and the
60 mixture was heated at $65{ }^{\circ} \mathrm{C}$ for 12 hours. The mixture was allowed to reach room temperature, the nanoparticles were separated and washed with water $(3 \times 5 \mathrm{~mL})$ and methanol $(3 \times 5$ $\mathrm{mL})$. The product was obtained as a brown solid $(0.122 \mathrm{~g})$, with a particle size of $5.56 \mathrm{~nm}(s=1.04)$. According to the $\% \mathrm{~N}$ ${ }_{65}$ determined by elemental analysis a functionalisation of the nanoparticles of $f=2.25 \mathrm{mmol} / \mathrm{g}$ was determined. According to the $\% \mathrm{P}$ determined by ICP-AES a functionalisation $f=2.28$ $\mathrm{mmol} / \mathrm{g}$ was calculated. Elemental analysis: $\mathrm{C}, 33.15 ; \mathrm{H}, 5.82 ; \mathrm{N}$, 9.11; P, 7.07. FTIR $v_{\max } / \mathrm{cm}^{-1} 2917,2851,2097,1079,560$.

Typical example of CuAAC reaction between functional magnetite nanoparticles 16 and alkynes: Synthesis of MNPs $17 \mathbf{a}$

75 Magnetite nanoparticles 16 (70 $\mathrm{mg}, f=2.25 \mathrm{mmol} / \mathrm{g})$ were dispersed in $5 \mathrm{~mL}$ dry DMF in a Schlenk flask under an argon atmosphere. The alkyne 10a (100 $\mathrm{mg}, 0.302 \mathrm{mmol})$, dissolved in $1 \mathrm{~mL}$ dry DMF was added to the suspension of the nanoparticles, followed by DIPEA $99.5 \%(0.474 \mathrm{~mL}, 352.0 \mathrm{mg}, 2.72 \mathrm{mmol})$, 80 and finally $\mathrm{CuI}(11.5 \mathrm{mg}, 0.0605 \mathrm{mmol})$ as a solid. The reaction mixture was magnetically stirred at $40{ }^{\circ} \mathrm{C}$ under argon. The progress of the reaction was monitored by IR spectroscopy, following the decrease of intensity of the azide band. If required, additional amounts of $\mathrm{CuI}$ and alkyne were added. Once the azide 85 band had dissapeared (between 4 to 7 days), the reaction mixture was cooled to room temperature, and the DMF was evaporated in the vaccum line to about one half of its volumen. Then, $40 \mathrm{~mL}$ of methanol (HPLC grade) were added and the particles left to precipitate overnight in the freezer, with the aid of an external 90 magnet. The supernatant was separated via cannula, the particles were washed twice with $5 \mathrm{~mL}$ methanol (HPLC grade) and two times with distilled water $(5 \mathrm{~mL}$ each) using centrifugation to separate the particles. The particles were again washed with methanol $(2 \times 5 \mathrm{~mL})$ and were dried with an argon stream. 66.6 $95 \mathrm{mg}$ of magnetite nanoparticles were isolated, with a particle size of $6.37 \mathrm{~nm}(s=1.08)$ and $f=1.00 \mathrm{mmol} / \mathrm{g}$. Elemental analysis: C, 36.65; H, 5.78; N, 4.24. FTIR $v_{\max } / \mathrm{cm}^{-1} 3445,2920,2851,1638$, $1467,1352,1291,1249,1106,1038,956,836,791,719$.

\section{${ }_{100}$ Preparation of functionalised polymers for metal extraction}

Typical functionalisation of (azidomethyl)polystyrene with crown ethers: Preparation of polystyrene resin 20a

105 Alkyne 10a (0.14 g, $0.421 \mathrm{mmol})$, DIPEA 99.5\% (0.384 mL, $2.202 \mathrm{mmol})$ and copper(I) iodide $(0.0043 \mathrm{~g}, 0.02 \mathrm{mmol})$ were added to a suspension of $0.22 \mathrm{~g}$ (azidomethyl)polystyrene $18(f=$ $0.77 \mathrm{mmol} / \mathrm{g})$ in $1: 1 \mathrm{DMF} / \mathrm{THF}(2 \mathrm{~mL})$ and the mixture was stirred at $40{ }^{\circ} \mathrm{C}$ for 5 days. The reaction mixture was monitored 110 and once the IR-signal of the azido group had completely disappeared, the resin was collected by filtration and sequentially washed with water $(60 \mathrm{~mL})$, THF $(60 \mathrm{~mL}), \mathrm{MeOH}(120 \mathrm{~mL})$ and THF $(60 \mathrm{~mL})$. The solid was dried in vacuo for 24 hours at $40{ }^{\circ} \mathrm{C}$ to afford $0.185 \mathrm{~g}$ of $\mathbf{1 0 a}$ with a functionalisation $f=0.597$ $115 \mathrm{mmol} / \mathrm{g}$. Elemental analysis: C, 79.96; H, 7.65; N, 2.51. FTIR $v_{\max } / \mathrm{cm}^{-1} 3059,3025,2919,2850,1945,1719,1601,1493,1451$, 1350, 1115, 1068, 903, 754, 693. ${ }^{1} \mathrm{H}$ NMR (500 MHz, $\left.\mathrm{CD}_{2} \mathrm{Cl}_{2}\right)$ 
$\delta_{\mathrm{H}} 7.46(\mathrm{H}$, triazole), $7.11(\mathrm{~s}, \mathrm{br}$, polymer backbone), 6.64 (s, br, polymer backbone), 5.37, $4.63\left(2 \mathrm{H}, \mathrm{s}\right.$ br) $3.74\left(2 \mathrm{H}, \mathrm{m}, \mathrm{CH}_{2}-\right.$ $\left.\mathrm{CH}_{2}-\mathrm{N}_{3}\right), 3.65$ (s, -(O- $\left.\left.\mathrm{CH}_{2}-\mathrm{CH}_{2}-\mathrm{O}\right)-\right), 1.86$ (s, polymer backbone), 1.52 (s, polymer backbone) ppm. ${ }^{13} \mathrm{C}$ NMR $\left(126 \mathrm{MHz}, \mathrm{CD}_{2} \mathrm{Cl}_{2}\right)$ ${ }_{5} \delta_{\mathrm{C}} 145.73,128.58,128.2,126.26,123.1$ (CH triazole), 111.30, 78.67, 71.09, 70.97, 70.06, 68.31, 65.28, $40.92 \mathrm{ppm}$.

Typical functionalisation of azido-polystyrene-polyethyleneglycol with crown ethers: Preparation of polystyrene${ }_{10}$ polyethyleneglycol resin 21a

Alkyne 10a (0.037 g, $0.113 \mathrm{mmol})$ dissolved in 1:1 DMF/THF (3 $\mathrm{mL})$, DIPEA $99.5 \%(0.17 \mathrm{~mL}, 0.975 \mathrm{mmol})$ and copper(I) iodide $(0.0015 \mathrm{~g}, 0.0075 \mathrm{mmol})$ were added to a suspension of $0.3 \mathrm{~g}$ of 15 azido-terminated polystyrene-polyethyleneglycol $19(f=0.25$ $\mathrm{mmol} / \mathrm{g})$ in $1: 1 \mathrm{DMF} / \mathrm{THF}(3 \mathrm{~mL})$ at $40{ }^{\circ} \mathrm{C}$ and the mixture was shaken for 24 hours. The reaction mixture was monitored and once the IR signal of the azido group had completely disappeared, the resin was collected by filtration and sequentially 20 washed with water $(180 \mathrm{~mL}), \mathrm{MeOH}(160 \mathrm{~mL})$ and THF $(160$ $\mathrm{mL}$ ). The solid was dried in vacuo for 24 hours at $40{ }^{\circ} \mathrm{C}$ to afford $0.203 \mathrm{~g}$ of $21 \mathrm{a}$ with $f=0.252 \mathrm{mmol} / \mathrm{g}$. Elemental analysis: C, 62.61; H, 8.74; N, 1.06; FTIR $v_{\max } / \mathrm{cm}^{-1} 2865,1638,1602,1492$, 1453, 1348, 1296, 1249, 1093, 946, 845, 761, 701; ${ }^{1} \mathrm{H}$ NMR (500 $\left.{ }_{25} \mathrm{MHz}, \mathrm{CD}_{2} \mathrm{Cl}_{2}\right) \delta_{\mathrm{H}} 7.79(1 \mathrm{H}, \mathrm{s}$, triazole), $7.04(\mathrm{~s}, \mathrm{br}$, polymer backbone), 6.57 (s, br, polymer backbone), 4.60 (2 H, s), 4.52 (2 $\mathrm{H}, \mathrm{s}), 3.86,3.72,3.59,3.45,2.09,1.73$ (s, br, polymer backbone). ${ }^{13} \mathrm{C}$ NMR $\left(126 \mathrm{MHz}, \mathrm{CD}_{2} \mathrm{Cl}_{2}\right) \delta_{\mathrm{C}} 145.3$ 128.5, 110.2, 85.3, 71.9, $70.8,70.5,69.7,50.5,40.9$.

Metal extraction experiments using functionalised MNPs and resins

General procedure for the $\mathrm{Pb}^{2+}$ extraction from acetonitrile 35 Solutions with nanoparticles

An exactly measured aliquot $(5 \mathrm{~mL})$ of a solution of $\mathrm{Pb}\left(\mathrm{ClO}_{4}\right)_{2}$ (of around $83 \mathrm{ppm}$ ) was added to a closed vial containing an equimolar amount of functional MNPs. The samples were 40 sonicated for at least $15 \mathrm{~min}$ to achieve the dispersion of the nanoparticles and the vials were shaken on a horizontal shaker for specified periods of time. The nanoparticles were then magnetically decanted with the help of an external magnet. The supernatant was transferred via cannula to a Schlenk flask, the ${ }_{45}$ solvent was evaporated under vaccum and the residue was dissolved in an exactly measured volume of $1 \% \mathrm{v} / \mathrm{v} \mathrm{HNO}_{3}$. The concentration of lead in the supernatant was determined by FAAS.

\section{${ }_{50}$ General procedure for the $\mathbf{P b}^{2+}$ extraction from aqueous solutions with nanoparticles}

An aliquot $(5 \mathrm{~mL})$ of a solution of $\mathrm{Pb}\left(\mathrm{ClO}_{4}\right)_{2}$ (of around $83 \mathrm{ppm}$ ) was added to a closed vial containing the required amount of ${ }_{55}$ magnetite nanoparticles. The samples were sonicated for at least 15 min to achieve the dispersion of the nanoparticles and the vials were shaken on a horizontal shaker for specified periods of time. The nanoparticles were then magnetically decanted with the help of an external magnet. The supernatant was separated with a
${ }_{60}$ syringe, filtrated through a Nylon filter $(0.45 \mu \mathrm{m})$ and acidified with concentrated $\mathrm{HNO}_{3}(65 \%$, puriss. p.a. grade) to achieve a final acid concentration of $1 \% \mathrm{v} / \mathrm{v}$. The concentration of lead in the supernatant was determined by FAAS.

\section{${ }_{65}$ General procedure for the $\mathrm{Pb}^{2+}$ extraction from aqueous solutions with PS resins}

An aliquot $(5 \mathrm{~mL})$ of a solution of $\mathrm{Pb}\left(\mathrm{ClO}_{4}\right)_{2}$ was added to a closed vial containing the required amount of polymer. The 70 samples were orbitally shaken on a horizontal shaker for specified periods of time. The samples were allowed to decant and a $2 \mathrm{~mL}$ aliquot of the supernatant was transferred to another vial, evaporated to dryness in an argon stream and the residue was dissolved in $5 \mathrm{~mL}$ aqueous $1 \% \mathrm{v} / \mathrm{v} \mathrm{HNO}_{3}$. The concentration 75 of lead in the supernatant was determined by FAAS.

General procedure for the $\mathrm{Pb}^{2+}$ extraction from aqueous solutions with PS and PS-PEG resins

${ }_{80}$ An aliquot $(5 \mathrm{~mL})$ of a solution of $\mathrm{Pb}\left(\mathrm{ClO}_{4}\right)_{2}$ (of around $83 \mathrm{ppm}$ ) was added to a closed vial containing the required amount of polymer. The samples were shaken on a horizontal shaker for specified periods of time. The samples were allowed to decantate and the supernatant was separated with a syringe, filtered through 85 a Nylon filter $(0.45 \mu \mathrm{m})$ and acidified with concentrated $\mathrm{HNO}_{3}$ $(65 \%$, purissim. p.a. grade) to achieve a final acid concentration of $1 \% \mathrm{v} / \mathrm{v}$. The concentration of lead in the supernatant was determined by FAAS.

\section{Conclusions}

90 In summary, we have shown that CuAAC reactions (the popular and widely used click chemistry) can be used as a most practical ligation methods for the preparation of immobilized complexing agents involving a clickable crown ether or aza-crown ether complexing unit and a support allowing easy separation (a 95 magnetic nanoparticle or a resin). The prepared library of clicked extractants covers different types of magnetic nanoparticles $(\varepsilon-\mathrm{Co}$ and $\mathrm{Fe}_{3} \mathrm{O}_{4}$ ) and resins (PS and PS-PEG), different approaches to the binding of the azido group to the nanoparticles (two-point carboxylic acid binding, three-point phosphonic acid binding and 100 covalent silicate binding through $\omega$-azidoalkyl(trialkoxy)silanes, and different spacer lengths separating the functional unit from the support. Some of these complex extracting materials, such as 11ai-bi, 20a-b, and 21a-b, are remarkably easy to prepare being only a few steps away from commercial precursors.

105 To illustrate the potential of this approach, we have studied the application of the clicked complexing agents to the removal of $\mathrm{Pb}^{2+}$ from aqueous and organic solutions. Remarkably, conditions have been developed for removing $>90 \%$ of the initial $\mathrm{Pb}^{2+}$ in a single operation from water and from organic solvents 110 (acetonitrile and tetrahydrofuran).

When the performance of both types of materials (MNP-based and resin-based) in the planned complexation of $\mathrm{Pb}^{2+}$ from its solutions is considered, the merits of functional polymers and functional nanoparticles depends on the nature of the media from 115 which $\mathrm{Pb}^{2+}$ needs to be extracted. To remove lead contamination from organic solvents, functional polymers such as 20a-b 
probably represent the best alternative. Thus, very high extraction levels $(>90 \%)$ can be achieved at stoichiometric extractant to $\mathrm{Pb}^{2+}$ ratios. On the other hand, small and readily dispersable, functional $\mathrm{Fe}_{3} \mathrm{O}_{4}$ nanoparticles offer the advantage of being 5 equally suitable for organic (11ai) and aqueous (17a) solutions, while functional polymers provides only mediocre results in this last situation. Taking into account the experimental simplicity of the complexation of the $\mathrm{Pb}^{2+}$ cations in combination with the ready separation of the corresponding complexes by magnetic

10 decantation, the use of complexing agents clicked onto MNPs offers substantial potential for future applications in the detoxification area.

\section{is Acknowledgement}

This work was funded by MINECO (grant CTQ2012-38594-C0201), DEC (grant 2014SGR827), EU-ITN network Mag(net)icFun (PITN-GA-2012-290248), and ICIQ Foundation. We also thank 20 MINECO for support through Severo Ochoa Excellence Accreditation 2014-2018 (SEV-2013-0319). C.M. thanks the ICIQ foundation and Agencia de Gestió d'Ajuts Universitaris i de Recerca (AGAUR) for a predoctoral fellowship.

\section{${ }_{25}$ Notes and references}

a Institute of Chemical Research of Catalonia (ICIQ), Avgda. Països Catalans, 16. E-43007 Tarragona, Spain. Fax: +34 977920244; Tel: +34 977920243; E-mail: mapericas@iciq.es

${ }^{b}$ Department of Chemistry, Imperial College London, South Kensington, 30 London SW7 2AY, UK; Tel: +44(0)2075941967; E-mail: r.vilar@imperial.ac.uk

${ }^{c}$ Departament de Química Orgànica, Universitat de Barcelona, c/ Martí $i$ Franqués 1-11, 08080, Barcelona, Spain.

$\dagger$ Electronic Supplementary Information (ESI) available: [details of any 35 supplementary information available should be included here]. See DOI: $10.1039 / \mathrm{b} 000000 \mathrm{x}$

1 C. J. Pedersen, J. Am. Chem. Soc., 1967, 89, 7017.

2 (a) F. L. Fu and Q. Wang, J. Environ. Manage, 2011, 92, 407; (b) D.

40 Zamboulis, E. N. Peleka, N. K. Lazaridis and K. A. Matis, J. Chem. Technol. Biotechnol., 2011, 86, 335; (c) A. Mudhoo, S. K. Sharma, V. K. Garg and C. H. Tseng, Crit. Rev. Env. Sci. Technol., 2011, 41, 435.

3 C. R. M. Rao and G. S. Reddi, TrAC, Trends Anal. Chem., 2000, 19, 565 .

4 (a) M. M. Jones, Crit. Rev. Toxicol., 1991, 21, 209; (b) A. E. V. Gorden, J. Xu, K. N. Raymond and P. Durbin, Chem. Rev., 2003, 103, 4207; (c) G. Crisponi and M. Remelli, Coord. Chem. Rev., 2008, 252, 1225; (d) M. Zhao, Y. Wang, C. Huo, J. Liu, C. Li, X. Zhang, L. Peng and S. Peng, Chem. Res. Toxicol., 2010, 23, 1282; (e) Y. Xu, Y. Wang, L. Wang, M. Zhao, X. Zhang, X. Hu, B. Hou, L. Peng, M. Zheng, J. Wu and S. Peng, Chem. Res. Toxicol., 2011, 24, 979.

5 (a) J. Hu, G. Chen and I. M. C. Lo, Water Res., 2005, 39, 4528; (b) A. Uheida, G. Salazar-Alvarez, E. Björkman, Z. Yu and M.

55 Muhammed, J. Colloid Interface Sci., 2006, 298, 501; (c) C. T. Yavuz, J. T. Mayo, W. W. Yu, A. Prakash, J. C. Falkner, S. Yean, L.
Cong, H. J. Shipley, A. Kan, M. Tomson, D. Natelson and V. L. Colvin, Science, 2006, 314, 964.

6 (a) W.-x. Zhang, J. Nanopart. Res., 2003, 5, 323; (b) A. B. Cundy, L. Hopkinson and R. L.D.Whitby, Sci. Total Environ., 2008, 400, 42.

7 (a) A.-H. Lu, E. L. Salabas and F. Schüth, Angew. Chem. Int. Ed., 2007, 46, 1222; (b) S. Laurent, D. Forge, M. Port, A. Roch, C. Robic, L. V. Elst and R. N. Muller, Chem. Rev., 2008, 108, 2064; (c) J. Gao, H. Gu and B. Xu, Acc. Chem. Res., 2009, 42, 1097; (d) S. Shylesh, V. 65 Schünemann and W. R. Thiel, Angew. Chem. Int. Ed., 2010, 49, 3428; (e) C. Boyer, M. R. Whittaker, V. Bulmus, J. Liu and T. P. Davis, NPG Asia Mater., 2010, 2, 23; (f) C. W. Lim and I. S. Lee, Nano Today, 2010, 5, 412; (g) L. M. Rossi, N. J. S. Costa, F. P. Silva and Wojcieszak, Green Chem., 2014, 16, 2906; (h) D. Wang and D. Astruc, Chem. Rev., 2014, 114, 6949.

8 (a) B. Hai, J. Wu, X. F. Chen, J. D. Protasiewicz and D. A. Scherson, Langmuir, 2005, 21, 3104; (b) Y.-C. Chang and D.-H. Chen, J. Colloid Interface Sci., 2005, 283, 446; (c) A. Uheida, M. Iglesias, C. Fontàs, Y. Zhang and M. Muhammed, Sep. Sci. Technol., 2006, 41, 909; (d) L. Wang, Z. Yang, J. Gao, K. Xu, H. Gu, B. Zhang, X. Zhang and B. Xu, J. Am. Chem. Soc., 2006, 128, 13358; (e) L. L. Vatta, J. Kramer and K. R. Koch, Sep. Sci. Technol., 2007, 42, 1985; (f) C. L. Warner, R. S. Addleman, A. D. Cinson, T. C. Droubay, M. H. Engelhard, M. A. Nash, W. Yantasee and M. G. Warner, ChemSusChem, 2010, 3, 749.

9 S. Shin and J. Jang, Chem. Commun., 2007, 4230.

10 W. Yantasee, C. L. Warner, T. Sangvanich, R. S. Addleman, T. G. Carter, R. J. Wiacek, G. E. Fryxell, C. Timchalk and M. G. Warner, Environ. Sci. Technol., 2007, 41, 5114.

8511 H. Y. Lee, D. R. Bae, J. C. Park, H. Song, W. S. Han and J. H. Jung, Angew. Chem. Int. Ed., 2009, 48, 1239.

12 F. M. Koehler, M. Rossier, M. Waelle, E. K. Athanassiou, L. K. Limbach, R. N. Grass, D. Günther and W. J. Stark, Chem. Commun., 2009,4862 .

9013 (a) D. W. Kim, H. J. Kim, J. S. Jeon, K. Y. Choi and Y. S. Jeon, J. Radioanal. Nucl. Chem., 2000, 245, 571; (b) D. W. Kim and B. M. Kang, J. Radioanal. Nucl. Chem., 2001, 249, 577.

14 L. G. A. van de Water, W. L. Driessen, J. Reedijk and D. C. Sherrington, Eur. J. Inorg. Chem., 2002, 221.

9515 (a) V. V. Rostovtsev, L. G. Green, V. V. Fokin and K. B. Sharpless, Angew. Chem. Int. Ed., 2002, 41, 2596; (b) M. Meldal, C. Christensen and C. W. Tornoe, J. Org. Chem. 2002, 67, 3057.

16 H. C. Kolb, M. G. Finn and K. B. Sharpless, Angew. Chem. Int. Ed., 2001, 40, 2004.

10017 For early examples of catalyst immobilization using CuAAC reactions, see: (a) A. Gheorghe, A. Matsuno and O. Reiser, Adv. Synth. Catal. 2006, 348, 1016; (b) D. Font, C. Jimeno and M. A. Pericàs, Org. Lett., 2006, 8, 4653; (c) M. Tilliet, S. Lundgren, C. Moberg and V. Levacher, Adv. Synth. Catal., 2007, 349, 2079; (d) D.

105 Font, S. Sayalero, A. Bastero, C. Jimeno and M. A. Pericàs, Org. Lett., 2008, 10, 337.

18 For a comprehensive review on immobilization of catalysts through click chemistry, see: A. E. Fernandes, A. M. Jonas and O. Riant, Tetrahedron, 2014, 70, 1709.

11019 The same strategy has been used by the Reiser laboratory for the functionalization of carbon-coated cobalt nanoparticles. See: Q. M. 
Kainz, S. Fernandes, C. M. Eichenseer, F. Besostri, H. Körner, R. Muller and O. Reiser, Faraday Discuss., 2014, 175, 27.

20 (a) M. A. White, J. A. Johnson, J. T. Koberstein and N. J. Turro, J. Am. Chem. Soc., 2006, 128, 11356; (b) D. A. Fleming, C. J. Thode and M. E. Williams, Chem. Mater., 2006, 18, 2327; (c) G. Chouhan, D. Wang and H. Alper, Chem. Commun., 2007, 4809; (d) L. Polito, D. Monti, E. Caneva, E. Delnevo, G. Russo and D. Prosperi, Chem. Commun., 2008, 621.

21 (a) A. Lagunas, C. Jimeno, D. Font, L. Solà and M. A. Pericàs,

10 Langmuir, 2006, 22, 3823; (b) A. Lagunas, A. Mairata i Payeras, C. Jimeno, V. F. Puntes and M. A. Pericàs, Chem. Mater., 2008, 20, 92; (c) F. Michalek, A. Lagunas, C. Jimeno and M. A. Pericàs, J. Mater. Chem., 2008, 18, 4692.

22 (a) P. Riente, C. Mendoza and M. A. Pericàs, J. Mater. Chem., 2011,

15 21, 7350; (b) P. Riente, J. Yadav and M. A. Pericàs, Org. Lett., 2012, 14, 3668; (c) L. Vaquer, P. Riente, X. Sala, S. Jansat, J. BenetBuchholz, A. Llobet and M. A. Pericàs, Cat. Sci. Technol., 2013, 3, 706.

23 S. Roy and M. A. Pericas, Org. Biomol. Chem., 2009, 7, 2669.

2024 (a) J. W. Steed, Coord. Chem. Rev., 2001, 215, 171 ; (b) G. W. Gokel, W. M. Leevy and M. E. Weber, Chem. Rev., 2004, 104, 2723; (c) For the catalytic use of magnetic nanoparticle-supported crown ethers, see: M. Kawamura and K. Sato, Chem. Commun., 2007, 3404.

25 For the use of core-shell $\mathrm{Co} / \mathrm{C}$ nanoparticles functionalized with

25 poly(ethyleneimine) units for the removal of mercury(II) from aqueous solutions, see: S. Fernandes, C. M. Eichenseer, P. Kreitmeier, J. Rewitzer, V. Zlateski, R. N. Grass, W. J. Stark and O. Reiser, RSC Advances 2015, 5, 46430.

26 R. M. Izatt, R. E. Terry, B. L. Haymore, L. D. Hansen, N. K. Dalley,

30 A. G. Avondet and J. J. Christensen, J. Am. Chem. Soc. 1976, 98, 7620.

27 R. M. Izatt, K. Pawlak, J. S. Bradshaw and R. L. Bruening, Chem. Rev. 1991, 91, 1721.

28 R. M. Izatt, J. S. Bradshaw, S. A. Nielsen, J. D. Lamb and J. J. Christensen, Chem. Rev. 1985, 85, 271.

29 K. Byriel, K. R. Dunster, L. R. Gahan, C. H. L. Kennard, J. L. Latten and I. L. Swann, Polyhedron 1992, 11, 1205.

30 U. Jeong, X. W. Teng, Y. Wang, H. Yang and Y. N. Xia, Adv. Mater., 2007, 19, 33.

4031 (a) V. F. Puntes, K. M. Krishnan and A. P. Alivisatos, Science, 2001, 291, 2115; (b) V. F. Puntes, D. Zanchet, C. K. Erdonmez and A. P. Alivisatos, J. Am. Chem. Soc., 2002, 124, 12874; (c) For a mechanistic study, see: A. Lagunas, D. Font, L. Solà, C. Jimeno and M. A. Pericàs, Langmuir 2006, 22, 3823.

4532 V. F. Puntes, K. M. Krishnan and P. Alivisatos, Appl. Phys. Lett., 2001, 78, 2187.

33 (a) K. S. Moon, E. Lee, Y. B. Lim and M. Lee, Chem. Commun., 2008, 4001; (b) W. P. Heal, S. R. Wickramasinghe, P. W. Bowyer, A. A. Holder, D. F. Smith, R. J. Leatherbarrow and E. W. Tate, Chem.

50 Commun., 2008, 480.

34 L. Shen, P. E. Laibinis and T. A. Hatton, Langmuir, 1999, 15, 447.

35 S. Y. Lee and M. T. Harris, J. Colloid Interface Sci., 2006, 293, 401.

36 R. De Palma, S. Peeters, M. J. Van Bael, H. Van den Rul, K. Bonroy, W. Laureyn, J. Mullens, G. Borghs and G. Maes, Chem. Mater., 2007, 19, 1821.
37 (a) B. P. Pichon, M. Wong Chi Man, C. Bied and J. J. E. Moreau, J. Organomet. Chem., 2006, 691, 1126; (b) C. A. Bradley, B. D. Yuhas, M. J. McMurdo and T. D. Tilley, Chem. Mater., 2009, 21, 174; (c) P. Paoprasert, J. W. Spalenka, D. L. Peterson, R. E. Ruther, R. J. 60 Hamers, P. G. Evans and P. Gopalan, J. Mater. Chem., 2010, 20, 2651.

38 The extent of the ligand substitution process can be estimated from the results of the elemental analysis of 9i-9iii $(\mathrm{C}[\%] / \mathrm{N}[\%]$ ratio, by assuming that all the organic matter present on the nanoparticles is oleic acid or the exchanged $\omega$-azidoalkyltris(oxy)silane. In this way, the following ligand exchange extents [in $\omega$-azidoalkyltris(oxy)silane \%] result: 9i [80]; 9ii [60]; 9iii [60].

39 The fraction of nanoparticle area occupied by the $\omega$ azidoalkyltris(oxy)silane ligands can be calculated from the oleic acid/silane ligand composition, ${ }^{38}$ the radii of the nanoparticles measured by TEM and the weight loss in TGA using simple mathematical formulae. ${ }^{36}$ In this way, the following values [\% area] are obtained: 9i [18]; 9ii [13]; 9iii [14].

40 (a) S. Özçubukçu, E. Ozkal, C. Jimeno and M. A. Pericàs, Org. Lett., 2009, 11, 4680; (b) E. Ozkal, S. Özçubukçu, C. Jimeno and M. A. Pericàs, Cat. Sci. Technol., 2012, 2, 195; (c) E. Ozkal, P. Llanes, F. Bravo, A. Ferrali and M. A. Pericàs, Adv. Synth. Catal., 2014, 356, 857; (d) L. Maestre, E. Ozkal, C. Ayats, A. Beltrán, M. M. DíazRequejo, P. J. Pérez and M. A. Pericàs, Chem. Sci., 2015, 6, 1510.

${ }_{80} 41$ (a) H. J. Deussen, S. Danielsen, J. Breinholt and T. V. Borchert, Biorg. Med. Chem., 2000, 8, 507; (b) J. R. Carlise and M. Weck, J. Polym. Sci., Part A: Polym. Chem., 2004, 42, 2973; (c) N. Mizoshita and T. Kato, Adv. Funct. Mater., 2006, 16, 2218; (d) A. Pulsipher, N. P. Westcott, W. Luo and M. N. Yousaf, J. Am. Chem. Soc., 2009, 131, 7626.

42 (a) S. H. Sun and H. Zeng, J. Am. Chem. Soc., 2002, 124, 8204; (b) S. Sun, H. Zeng, D. B. Robinson, S. Raoux, P. M. Rice, S. X. Wang and G. Li, J. Am. Chem. Soc., 2004, 126, 273.

43 For most recent work on this topic, see: (a) X. Cai, J. Li, Z. Zhang, 90 F. Yang, R. Dong and L. Chen, ACS Appl. Mater. Inter., 2014, 6, 305; (b) J. Ma, G. Cheng, S. Basov, S. Zhang and T. Ji, Desalin. Water Treat., 2014, 52, 7898; (c) B. B. Adhikari, M. Gurung, H. Kawakita, and K. Ohto, Solvent Extr. Ion Exc., 2013, 31, 483. 